\title{
Ptosis-vocal cord paralysis syndrome
}

INSERM

\section{Source}

INSERM. (1999). Orphanet: an online rare disease and orphan drug data base. Ptosisvocal cord paralysis syndrome. ORPHA:2997

Ptosis-vocal cord paralysis syndrome is a rare, hereditary disorder with ptosis characterized by the combination of cong enital bilateral recurrent laryngeal nerve paralysis and cong enital bilateral ptosis. There have been no further descriptions in the literature since 1983. 